\title{
Nutritional status of apple orchards soils in district Qilla Saifullah (Balochistan)
}

\author{
Zia ul Haq ${ }^{1}$, Zafar Ullah'², Saeed Ahmed ${ }^{2}$, Muhammad Raza \\ Siddiqui ${ }^{2}$ and Saduddin ${ }^{2}$ \\ 1. Agriculture University Peshawar, Khyber Pakhtunkhwa-Pakistan \\ 2. Balochistan Agricultue College, University of Balochistan, Quetta-Pakistan \\ *Corresponding author's email: zumalghani@gmail.com \\ Citation
}

Zia ul Haq, Zafar Ullah, Saeed Ahmed, Muhammad Raza Siddiqui and Saduddin. Nutritional status of apple orchards soils in district Qilla Saifullah (Balochistan). Pure and Applied Biology. Vol. 7, Issue 2, pp797-809. http://dx.doi.org/10.19045/bspab.2018.70099

\begin{tabular}{llll}
\hline \hline Received: 31/03/2018 & Revised: 29/05/2018 & Accepted: 19/06/2018 & Online First: 28/06/2018 \\
\hline \hline
\end{tabular}

\section{Abstract}

This research was conducted to study the nutritional status of apple orchards soils in Qilla Saifullah during November, 2011. Soil samples were collected from three depths 0-30, 31-60 and 61-90 cm and analyzed for mineral N, hot water soluble B and AB-DTPA extractable P, $\mathrm{K}, \mathrm{Zn}, \mathrm{Cu}, \mathrm{Fe}$ and $\mathrm{Mn}$. The majority of soils were light in texture, alkaline in reaction, nonsaline and moderately calcareous. The concentration of $\mathrm{N}$ showed that about $77 \%$ of the surface soils were adequate in $\mathrm{N}$. The concentration of extractable $\mathrm{P}$ was also adequate in $80 \%$ samples. The $\mathrm{K}$ content showed that 3, 20 and $60 \%$ soils in 0-30, 31-60 and 61-90 cm depths, respectively were low. The orchards more than $85 \%$ were found low in organic matter. The analysis of AB-DTPA extractable $\mathrm{Zn}$ showed that 7, 23 and 47\% soils in 0-30, 31-60 and 61$90 \mathrm{~cm}$ depth respectively were low. The $\mathrm{Cu}$ and $\mathrm{Mn}$ results showed that none of orchards were found deficient in all three depths. The results of B showed that $17 \%$ in $61-90 \mathrm{~cm}$ depth was low whereas $77,57 \%$ and $47 \%$ in three depths, respectively were adequate. The soils of apple orchards were low to marginal in $\mathrm{Zn}, \mathrm{Fe}$ and $\mathrm{B}$ to varying levels. The frequency of $\mathrm{Zn}$ deficiency was highest followed by Fe and B. AB-DTPA nutrients showed different correlation trends for organic matter, $\mathrm{pH}$ and $\mathrm{EC}$. The AB-DTPA extractable $\mathrm{Zn}, \mathrm{Fe}, \mathrm{Cu}, \mathrm{Mn}$ and $\mathrm{B}$ had positive non-significant correlation with organic matter in the surface and subsurface soil. Micronutrients such as $\mathrm{Zn}$ and $\mathrm{Fe}$ had negative and non-significant correlation with EC and $\mathrm{pH}$. The AB-DTPA extractable phosphorus showed positive non-significant correlation with organic matter. The AB-DTPA extractable potash had positive significant correlation with lime and organic matter in the surface and subsurface soils and negative non-significant correlation with $\mathrm{pH}$.

Keywords: Apple; Balochistan; Extractable P; Mineral N; Nutritional status; Soils

\section{Introduction}

Apple (Mallus domestica authority) is a deciduous fruit and belongs to the family Rosaceae. In Pakistan, it is mainly grown in Balochistan and Khyber Pakhtunkhwa (KP). Red Delicious and Golden Delicious are two important verities of apple grown worldwide. Verities of apple grown grown in Qilla Saifullah, Balochistan region are
Red, Golden delicious, Kaja. Red Super.

Royal gala. Amri and Mashadi [1]. The soil and climatic condition of Balochistan are well suited for the production of apple. In Pakistan 110.6 thousand hectares of land is under apple orchards with a production of 525.9 thousand tons. In Balochistan, the area under apple orchards was 102.2 thousand hectare producing 
426.8 thousand tons apple [2]. Qilla Saifullah is location in North West Balochistan. Zhob is located in the east of Qilla Saifullah, while Pishin is in the west, in the same way its border touches to
Afghanistan and loralai in the north and south, respectively (Figure 1). Qilla Saifullah has been popular for its agriculture and livestock.

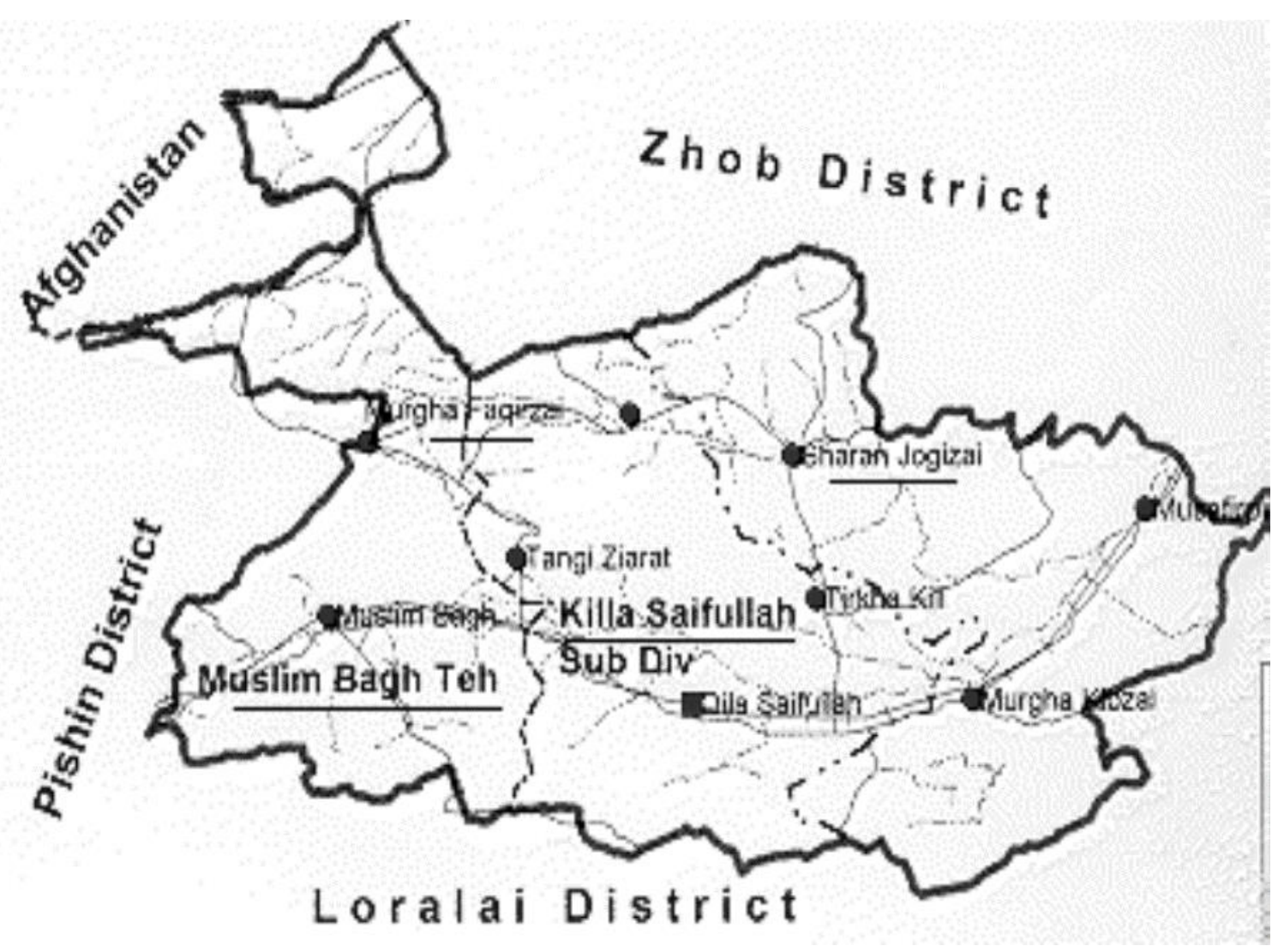

Figure 1. Map of the Qilla Saifullah (Balochistan)

Nitrogen $(\mathrm{N})$ is a necessary part of all proteins, all living cells and chlorophyll as well, enzymes and metabolic processes concerned in the synthesis and move of energy, the green color of the plant that is accountable for photosynthesis [3]. Nitrogen $(\mathrm{N})$ and phosphorus (P) are necessary for photosynthesis, in the structure of all sugars, oils and starches, Support with the alteration of solar energy into chemical energy and help in plant maturation by quick root growth as well as encourage blooming, [4]. The plants mostly absorbed Potassium (K) more than other element except nitrogen and, while calcium supports to build the protein and fruit quality [3]. Calcium (Ca) is an important for plant cell wall structure, to give common transport and maintenance of other elements to strengthen the plant. It is also effect of organic acids and alkali salts in a plant [4]. Magnesium (Mg) plays pivotal role in chlorophyll, photosynthesis, enzyme activity and response to soil minerals and fertilizers.

Macronutrients and micronutrients, both are essential and play important role in plant growth and productions as influence on many metabolic activities and enzymatic reactions. e.g., zinc ( $\mathrm{Zn}$ ) plays an important role as a structural constituent of a broad range of enzymes in many biochemical pathways plus protein, axon and carbohydrate. These are a part of enzymes such as peptidase, posphohydrolase, dehydrogenate and 
proteins, $[4,5]$.

Equally copper $(\mathrm{Cu})$ is an element of laccase and cytochrome oxidase, ascorbic acid oxidase and plays a vital role in respiration, photosynthesis, and carbohydrate metabolism. Iron (Fe) plays key role in photosynthesis, nitrogen fixation and energy transformation and hemo-proteins and nonhomo-proteins, ferrodoxins and oxidation-reduction in respiration. Manganese $(\mathrm{Mn})$ is a component of enzymes anginase and phosphotransferase, helps in nucleic acid synthesis, and cell wall and tissue formation [6]. Boron (B) activates dehydrogenase, facilitates sugar translocation and helps in the synthesis of plant hormones, nucleic acids and cell division of cell.

The deficiency of micronutrients causes irregular growth of plants that consequence in partial failure of plants. Grain and flower formation fails to develop in severe deficiency. The deficiencies of Micronutrients such as boron $[5,7]$ for a long time reported to potentially cause main problems for apples.

There is need to know the status of the micronutrients in soils and to plan to eliminate deficiencies of micronutrients to improve production, and such informations are limited for apple orchards in Qilla Saifullah. Therefore, this research was planned to assess the nutritional status of apple orchards soils. Specific objectives were: 1) to determine the concentration of macronutrients ( $\mathrm{N}, \mathrm{P}$ and $\mathrm{K}$ ) in soil of apple orchards, 2) to assess the AB-DTPA extractable micronutrients ( $\mathrm{Zn}, \mathrm{Cu}, \mathrm{Fe}, \mathrm{Mn}$ and B) in apple orchards and 3) to compare the micronutrients status with the standard criteria for nutrient indexation.

\section{Materials and methods}

The proposed study was conducted to assess the nutritional status of soil of 30 apple orchards in district Qilla Saifullah, Balochistan during November, 2011. Soil samples from three depth i.e. 0-30, 31-60 and $61-90 \mathrm{~cm}$ from different orchards were collected. Each sample was a composite of 10-15 locations from the same orchard. Soil samples were suitably packed, labeled and transferred to the laboratory of Soil \& Environmental Sciences Department, Agriculture University Peshawar, Khyber Pakhtunkhwa. After air-drying, twigs and stones were removed from soil samples, ground and passed through $2 \mathrm{~mm}$ sieve and stored for laboratory analysis.

\section{Laboratory analyses}

The soil samples were extracted with ABDTPA solution as described by [8] and ready for $\mathrm{P}$ by spectrophotometer, $\mathrm{K}$ by flame photometer and $\mathrm{Zn}, \mathrm{Cu}, \mathrm{Fe}$ and $\mathrm{Mn}$ determined by Atomic Absorption Spectrophotometer and $\mathrm{N}$ by Kjeldal apparatus [9]. $20 \mathrm{~g}$ of soil samples with 40 $\mathrm{ml}$ of distilled water and $0.5 \mathrm{ml}$ of 10 percent. $\mathrm{BaCl}_{2}$ solution was boiled for 5 minutes under reflux condenser [10]. One $\mathrm{ml}$ of the acidified aliquot containing $4 \mathrm{ml}$ curcumine-oxalic acid was dried on water bath at temperature $50 \pm 3^{\circ} \mathrm{C}$ and based for 15 minutes then dissolved in $25 \mathrm{ml}$ of 95 percent ethanol, centrifuged and reading were taken on spectrophotometer [11]. Organic matter in soil samples were determined by the Walkyley-Black procedure [12]. $1 \mathrm{~g}$ soil sample was treated with $10 \mathrm{ml}$ of $1 \mathrm{~N} \mathrm{~K}_{2} \mathrm{Cr}_{2} \mathrm{O}_{7}$ and $20 \mathrm{ml}$ of concentrated $\mathrm{H}_{2} \mathrm{SO}_{4}$. After adding $200 \mathrm{ml}$ distilled water upon cooling, the suspension was filtered and the filtrate was titrated against $0.5 \mathrm{~N} \mathrm{FeSO}_{4}$ solution using Ortho-phenolphthalein as indicator with the appearance of maroon color as end point. A blank sample was run simultaneously with the soil samples. The amount of organic matter was calculated from the moles of $\mathrm{K}_{2} \mathrm{Cr}_{2} \mathrm{O}_{7}$ utilized in the oxidation of organic $\mathrm{C}$ in soil. Soil $\mathrm{pH}$ and EC were determined in soil-water (1:5) suspension. For this, $10 \mathrm{~g}$ soil was shaken with $50 \mathrm{ml}$ distilled water for $30 \mathrm{~min}$. After filtering, the extract was read on $\mathrm{pH}$ meter (InoLab pH level 1) and EC on Conductivity meter (DDC-308A) [13]. 50 $\mathrm{g}$ air-dry soil was dispersed with $5 \mathrm{ml} 10 \%$ sodium hexametaphosphate solution in a 
mechanical dispersion machine for $5 \mathrm{~min}$. After quantities transfer of the suspension to a $1 \mathrm{~L}$ Bouyoiucos cylinder, filling the cylinder with distilled water to $1 \mathrm{~L}$ mark. After thorough mixing, carefully inserted a hydrometer in the suspension and took the hydrometer reading after $40 \mathrm{sec}$ for silt + clay and after 2 hour for clay. Also note temperature of the suspension with each hydrometer reading and made necessary correction in the hydrometer readings. Percent silt and clay were calculated from hydrometer readings while \% sand was calculated by difference. Percent sand silt and clay were used to determined soil textural class on the USDA soil textural triangle. The lime content was determinate by acid naturalization (Method 23c, USDA HB 60). Five g soil was transferred to $150-\mathrm{ml}$ flask and mix with $50 \mathrm{ml} 0.5 \mathrm{~N}$ $\mathrm{HCl}$. The suspension was boiled for $5 \mathrm{~min}$ and then filtered through filter paper 40 . After cooling, the filtrate was titrated against $0.25 \mathrm{~N} \quad \mathrm{NaOH}$ by adding phenolphthalein as indicator till pink color appeared.

\section{Statistical analysis}

Descriptive statistics were used to calculate mean, standard deviation and coefficient of variation [14]. Nutrient status was compared with standard criteria for nutrient indexation.

\section{Results and discussion \\ Physical and chemical properties}

The results obtained on particle soil analysis of apple orchards are presented in (Table 1). It is clear that the soil is normally comprised of large amount of silt followed by sand with less amount of clay. Majority of soils were silt loam (58 samples) and sandy loam (16 samples) and clay loam (12 samples), salty (2 samples) and loamy (2 samples) in texture. These results suggested that the soils of apple orchards were generally light in texture [15]. The results obtained on $\mathrm{pH}$ of soils of apple orchards are presented in (Table 1-3). The results showed that the soil $\mathrm{pH}$ of selected soil series ranged from 6.4 to 8.8. These results suggested that the soils of apple orchards were generally alkaline in reaction [16].

The results obtained on EC of soils of apple orchards are presented in (Table 1$3)$. The results showed that the EC of all soils at all the three depths of apple orchards was below $4.0 \mathrm{dSm}^{-1}$. These results suggested that the soils of apple orchards were non-saline [17]. The results obtained on lime content presented in (Table 4) showed that the surface $(0-30 \mathrm{~cm})$ soil, it ranged from 8.00 to 22.00 with a mean value of $15.63 \pm 3.99$. In the depth of (31-60 $\mathrm{cm})$ soil, it ranged from 6.00 to 20.00 with a mean value of $14.27 \pm 3.921$, the lime contents in the $(61-90 \mathrm{~cm})$ soil ranged from 4.00 to 20.00 with a mean value of $12.50 \pm 4.265$ of lime, generally alkaline in nature [18]. The results obtained on organic matter content in soils of apple orchards are presented in (Table $4 \& 5$ ). The results showed that the surface soils generally contained more organic matter than the soils at lower depths. In the surface soil, organic matter ranged from 0.50 to $1.12 \%$ with a mean value of $0.81 \pm 0.141$ (Table 5) in subsurface soil. It ranged from $0.45 \%$ to $1.02 \%$ with a mean value of $0.75 \pm 0.130$. In $(61-90 \mathrm{~cm})$ it ranged from $0.42 \%$ to $0.99 \%$ with a mean value of $0.66 \pm 0.128$. The organic matter contents at surface soil were low in 25 , marginal in 5 and in $(31-60 \mathrm{~cm})$ soil was low in 26, marginal in 4 orchards. In $(61-90 \mathrm{~cm})$ soil was low in 28 and marginal in 2 orchards. And none of the orchards were found adequate in all three depths. The results showed that $83 \%$ orchards were low in organic matter in $(0$ $30 \mathrm{~cm}), 87 \%$ in $(31-60 \mathrm{~cm})$ and $93 \%$ in $(61-90 \mathrm{~cm})$ soils. But $17 \%$ orchards were marginal in $(0-30 \mathrm{~cm}), 13 \%$ in $(31-60 \mathrm{~cm})$ and $7 \%$ in $(61-90 \mathrm{~cm})$ orchards and none of soil samples was adequate in surface soil while subsurface soil [19].

\section{Major nutrients}

Mineral nitrogen $\left(\mathrm{mgkg}^{-1}\right)$ and AB-DTPA extractable $\mathrm{P}$ and $\mathrm{K}$, and Organic matter content and $\mathrm{CaCO}_{3}$ of soil collected from apple orchards were also measured along with micronutrients and the results obtained 
are presented in (Tables 2-4) [20]. Data collected on mineral nitrogen in surface $(0$ $30 \mathrm{~cm}$ ) soils ranged from 11.17 to 61.17 $\mathrm{mgkg}^{-1}$ soils with mean value of $33.26 \pm 15.665$ (Table 1). In $(31-60 \mathrm{~cm}$ ) soil, it ranged from 9.87 to $52.30 \mathrm{mgkg}^{-1}$ soil with a mean value of $29.02 \pm 13.691$ while in $(61-90 \mathrm{~cm})$, it ranged from 7.66 to $45.61 \mathrm{mgkg}^{-1}$ soil with a mean value of $22.27 \pm 11.679$. The data showed that none of the orchard was found low in surface soil 1 and 4 orchards were found low in $(31-60 \mathrm{~cm})$ and $(61-90 \mathrm{~cm})$ depth respectively. 7, 9 and 11 orchards were found marginal and 23, 20 and 15 orchards were found adequate in nitrogen. The results showed that 3\% orchards were low in $(31-60 \mathrm{~cm}), 13 \%$ in $(61-90 \mathrm{~cm}), 23 \%$ marginal in $(0-30 \mathrm{~cm}), 30 \%$ in the $(31-60 \mathrm{~cm})$ and $37 \%$ in $(61-90 \mathrm{~cm})$ soil. The surface $(0-30 \mathrm{~cm})$ soil was adequate in $\mathrm{N}$ in $77 \%$ orchards in $(31-60 \mathrm{~cm})$ soil was adequate in $67 \%$ orchards While in $61-90$ $\mathrm{cm})$ soil was adequate in $50 \%$ orchards. The results were also showed by [21-23].

The AB-DTPA extractable P in soils of apple orchards are existed in (Table 2-4). The absorption of extractable $\mathrm{P}$ in soils different depths of orchards. The concentration of $\mathrm{P}$ was generally high in the surface depth and decreased gradually with increasing soil depth. The concentration of $\mathrm{P}$ in the $(0-30 \mathrm{~cm})$ soil ranged from 6.00 to $12.00 \mathrm{mg} \mathrm{kg}^{-1}$ soil with a mean value of $9.20 \pm 1.808$ (Table 2), in $(31-60 \mathrm{~cm})$ soil, it ranged from 6.00 to $12.00 \mathrm{mgkg}^{-1}$ soil with a mean value of $8.33 \pm 1.918$ and in $(61-90 \mathrm{~cm})$, it ranged from 5.00 to $11.00 \mathrm{mgkg}^{-1}$ soil with a mean value of $7.17 \pm 1.840$. Comparing with the critical values of $\mathrm{P}$ in soil reported by [8], the data showed that $\mathrm{P}$ was deficient in both surface and sub-surface soils of many orchards. It was obvious that the soils at lower depths in (31-60 and 61-90 cm) were more deficient in $\mathrm{P}$ than the surface $(0-30$ $\mathrm{cm})$ soil. The results showed that none of the orchards were found low in all three depths, marginal 6, 11 and 18, adequate 24, 19 and 12 orchards were found in (0-30, 3160 and $61-90 \mathrm{~cm}$ ) depths. Thus, 20\% orchards were marginal in $\mathrm{P}$ in $(0-30 \mathrm{~cm})$, $37 \%$ in $(31-60 \mathrm{~cm})$ and $60 \%$ in $(61-90 \mathrm{~cm})$ soil. However, $80 \%$ orchards were adequate in $\mathrm{P}$ in $(0-30 \mathrm{~cm}), 63 \%$ in $(31-60 \mathrm{~cm})$ and $40 \%$ in $(61-90 \mathrm{~cm})$ soil. Similar results were found by $[14,25]$.

The results obtained on AB-DTPA extractable $\mathrm{K}$ in soils of apple orchards are presented in (Table 2-4). The concentration of extractable $\mathrm{K}$ in soils varied with depth and with orchards. The concentration of $\mathrm{K}$ was greater in the surface $(0-30 \mathrm{~cm})$ soil compared with that at lower soil depths. The concentration of $\mathrm{K}$ in $(0-30 \mathrm{~cm})$ soil ranged from 60.00 to $85.00 \mathrm{mg} \mathrm{kg}^{-1}$ soil with a mean value of $70.83 \pm 6.958$ (Table 5). In $(31-60 \mathrm{~cm})$ soil it ranged from 60.00 to $80.00 \mathrm{mgkg}^{-1}$ soil with a mean value of $66.83 \pm 5.645$. In $(61-90 \mathrm{~cm})$, it ranged from 60.00 to $70.00 \mathrm{mgkg}^{-1}$ soil with a mean value of $62.83 \pm 3.869$. Comparing with the critical values of $\mathrm{K}$ in soil established by [8], the data showed that at lower depths $(31-60$ and $61-90 \mathrm{~cm})$ were more deficient in $\mathrm{K}$ than the surface $(0-30$ $\mathrm{cm})$ soil. The results showed that 1,6 and 18 orchards were found low in $(0-30,31-60$ and 6, marginal 29, 24 and 12 orchards were found in $(0-30,31-60$ and $61-90 \mathrm{~cm})$ depths, none of soil were found adequate in all three depths (Table 2) Thus, 3\% orchards were low in $\mathrm{K}$ in $(0-30 \mathrm{~cm}), 20 \%$ in $(31-60 \mathrm{~cm})$ and $60 \%$ in $(61-90 \mathrm{~cm})$ soil, and $97 \%$ orchards were marginal in $\mathrm{K}$ in $(0-30 \mathrm{~cm}), 80 \%$ in $(31-60 \mathrm{~cm})$ and $40 \%$ in $(61-90 \mathrm{~cm})$ soil. The recorded data were also reported by $[23,26]$.

The data obtained on concentration of ABDTPA extractable micronutrients in soils of apple orchards are presented in (Tables $5 \&$ 6). The concentration of micronutrients in soils varies with depth and with orchard. The concentration of $\mathrm{Zn}$ was generally high in $(0-30 \mathrm{~cm})$ soil but decreased gradually with increasing soil depth. The concentration of $\mathrm{Zn}$ in (0-30 $\mathrm{cm})$ ranged from 0.85 to $3.65 \mathrm{ugg}^{-1}$ soil with a mean value-of $2.10 \pm 0.819$ (Table $6)$. 
Table 1. Particle size soil analysis, pH, EC and Lime content (\%) of apple orchards in Qilla Saifullah

\begin{tabular}{|c|c|c|c|c|c|c|c|c|c|c|c|c|c|c|c|}
\hline \multirow{2}{*}{$\begin{array}{l}\text { Soil depth } \\
\text { (cm) }\end{array}$} & \multicolumn{5}{|c|}{ pH } & \multicolumn{5}{|c|}{ EC } & \multicolumn{5}{|c|}{ Lime content (\%) } \\
\hline & Mean & SD & Min. & Max. & $\begin{array}{l}\text { CV } \\
(\%)\end{array}$ & Mean & SD & Min. & Max. & CV (\%) & Mean & SD & Min. & Max. & $\mathrm{CV}(\%)$ \\
\hline $0-30$ & 7.70 & 0.476 & 6.44 & 8.80 & 6.18 & 1.60 & 0.485 & 0.79 & 2.45 & 30.31 & 15.63 & 3.99 & 8.00 & 22.00 & 25.52 \\
\hline $31-60$ & 7.66 & 0.437 & 6.42 & 8.16 & 5.70 & 1.28 & 0.445 & 0.62 & 1.98 & 34.76 & 14.27 & 3.921 & 6.00 & 20.00 & 27.47 \\
\hline $61-90$ & 7.62 & 0.440 & 6.40 & 8.20 & 5.77 & 1.00 & 0.345 & 0.45 & 1.88 & 34.5 & 12.50 & 4.265 & 4.00 & 20.00 & 34.12 \\
\hline \multicolumn{16}{|c|}{ Particle size soil analysis } \\
\hline Textural class & \multirow{2}{*}{\multicolumn{3}{|c|}{$\begin{array}{l}\text { Silt loam } \\
58\end{array}$}} & \multirow{2}{*}{\multicolumn{3}{|c|}{$\begin{array}{c}\text { Silt } \\
2\end{array}$}} & \multirow{2}{*}{\multicolumn{3}{|c|}{$\begin{array}{c}\text { Sandy loam } \\
16\end{array}$}} & \multirow{2}{*}{\multicolumn{3}{|c|}{$\frac{\text { Loam }}{2}$}} & \multicolumn{3}{|c|}{ Clay loam } \\
\hline No of samples & & & & & & & & & & & & & & 12 & \\
\hline
\end{tabular}

Table 2. Organic matter content (\%), Nitrogen content $\left(\mathrm{mg} \mathrm{kg}^{-1}\right)$ and Ammonium bicarbonate- DTPA extractable P concentration (mg $\mathrm{kg}^{-1}$ ) in soils of apple orchards

\begin{tabular}{|c|c|c|c|c|c|c|c|c|c|c|c|c|c|c|c|}
\hline \multirow{2}{*}{$\begin{array}{l}\text { oil depth } \\
\text { (cm) }\end{array}$} & \multicolumn{5}{|c|}{ Organic matter content (\%) } & \multicolumn{5}{|c|}{ Nitrogen content (mg kg-1) } & \multicolumn{5}{|c|}{$\begin{array}{c}\text { Ammonium bicarbonate- DTPA extractable } \\
\text { P concentration }\left(\mathrm{mg} \mathrm{kg}^{-1}\right)\end{array}$} \\
\hline & Mean & SD & Min. & Max. & CV $(\%)$ & Mean & SD & Min. & Max. & CV $(\%)$ & Mean & SD & Min. & Max. & CV $(\%)$ \\
\hline $0-30$ & 0.81 & 0.141 & 0.50 & 1.12 & 17.40 & 33.26 & 15.665 & 11.17 & 61.17 & 47.09 & 9.20 & 1.808 & 6.00 & 12.00 & 19.65 \\
\hline $31-60$ & 0.75 & 0.130 & 0.45 & 1.02 & 17.33 & 29.02 & 13.691 & 9.87 & 52.30 & 47.17 & 8.33 & 1.918 & 6.00 & 12.00 & 23.02 \\
\hline $61-90$ & 0.66 & 0.128 & 0.42 & 0.99 & 19.39 & 22.27 & 11.679 & 7.66 & 45.61 & 52.44 & 7.17 & 1.840 & 5.00 & 11.00 & 25.66 \\
\hline
\end{tabular}

Table 3. Number of apple orchards soils, classified as saline or non-saline, and acidic or alkaline

\begin{tabular}{|c|c|c|c|c|c|c|}
\hline \multirow{2}{*}{ Soil depth (cm) } & \multicolumn{2}{|c|}{$\mathrm{pH}(6.0-7.5)$} & \multicolumn{2}{|c|}{ pH (7.5-9.0) } & \multicolumn{2}{|c|}{$E C(<4.0 \mathrm{ds} / \mathrm{m})$} \\
\hline & No* of orchards & $\%$ & No & $\%$ & No & $\%$ \\
\hline $0-30$ & 11 & 36.66 & 19 & 63.66 & 30 & 100 \\
\hline $31-60$ & 12 & 40 & 18 & 60 & 30 & 100 \\
\hline $61-90$ & 12 & 40 & 18 & 60 & 30 & 100 \\
\hline
\end{tabular}

${ }^{*}$ Out of 30 orchard 
In $(31-60 \mathrm{~cm})$, it ranged from 0.54 to 2.63 $\mathrm{ugg}^{-1}$ soil with a mean value of $1.39 \pm 0.673$ and in $(61-90 \mathrm{~cm})$, it ranged from 0.32 to $2.44 \mathrm{ugg}^{-1}$ soil with a mean value of $1.00 \pm 0.535$. The concentration of $\mathrm{Cu}$ in soil also decreased gradually with increasing soil depth. The concentration of $\mathrm{Cu}$ in $(0-30 \mathrm{~cm})$, ranged from 2.01 to 6.16 $\mathrm{ugg}^{-1}$ soil with a mean value of $4.20 \pm 1.205$. In $(31-60 \mathrm{~cm})$, it ranged from 1.91 to $6.10 \mathrm{ugg}^{-1}$ soil with a mean value of $3.84 \pm 1.31 \mathrm{ugg}^{-1}$ and in $(61-90 \mathrm{~cm})$, it ranged from 1.11 to $5.91 \mathrm{ugg}^{-1}$ soil with a mean value of $3.55 \pm 1.383$. The concentration of $\mathrm{Fe}$ in soil also generally decreased gradually with increasing soil depth. The concentration of $\mathrm{Fe}$ in (0-30 $\mathrm{cm})$ ranged from 3.05 to $9.66 \mathrm{ugg}^{-1}$ soil with a mean value of $6.95 \pm 1.917$ in (31-60 $\mathrm{cm})$, it ranged from 2.34 to $8.89 \mathrm{ugg}^{-1}$ soil with a mean value of $6.40 \pm 1.858$ and in $(61-90 \mathrm{~cm})$, it ranged from 1.90 to 8.78 ugg $^{-1}$ soil with a mean value of $5.53 \pm 1.967$. Like other micronutrients, the concentration of $\mathrm{Mn}$ in soil was generally high in the surface soil but decreased gradually with increasing soil depth, in (0$30 \mathrm{~cm}$ ), ranged from 2.90 to $7.72 \mathrm{ugg}^{-1}$ soil with a mean value of $5.47 \pm 1.574$. In (31$60 \mathrm{~cm}$ ), it ranged from 2.56 to $7.01 \mathrm{ugg}^{-1}$ soil with a mean value of $4.76 \pm 1.475$ and in $(61-90 \mathrm{~cm})$, it ranged from 2.01 to 7.01 $\mathrm{ugg}^{-1}$ soil with a mean value of $4.23 \pm 1.459$. The concentration of $B$ in $(0-30 \mathrm{~cm})$ ranged from 0.72 to $3.16 \mathrm{ugg}^{-1}$ soil with a mean value of $1.68 \pm 0.706$. In $(31-60 \mathrm{~cm})$, it ranged from 0.55 to $3.05 \mathrm{ugg}^{-1}$ soil with a mean value of $1.44 \pm 0.756$ and in (61-90 $\mathrm{cm})$, it ranged from 0.29 to $2.98 \mathrm{ugg}^{-1}$ soil with a mean value of $1.21 \pm 0.775$.

Comparing with the critical values of micronutrients concentration in soil, the data showed that the soils of apple orchards incorporated in the survey were deficient in $\mathrm{Zn}, \mathrm{Fe}$ and $\mathrm{B}$ at varying levels. The $\mathrm{Zn}$ results showed that 2, 7 and 14 orchards were found low, marginal 7,11 and 12, adequate 21, 12 and 4 orchards were found in $(0-30,31-60$ and $61-90 \mathrm{~cm})$. The soils at lower depths $(31-60$ and $61-90 \mathrm{~cm})$ were more deficient in $\mathrm{Zn}$ than the surface (0-30 $\mathrm{cm})$ soils.

The $\mathrm{Zn}$ results showed that the orchards were low 7, 23 and 47\%, marginal 23, 37 and $40 \%$, adequate 70,40 and $13 \%$ in (0$30,31-60$ and $61-90 \mathrm{~cm}$ ). Similar results also found by [27]. And none of orchards were found deficient in $\mathrm{Cu}$ and $\mathrm{Mn}$ in at all three depths (Table 6). The results were found by [24, 28]. The results of Fe status in soil of apple orchards showed that none of the orchard was found low in surface (0$30 \mathrm{~cm}$ ), 1 and 3 orchards were found low in $(31-60 \mathrm{~cm})$ and $(61-90 \mathrm{~cm})$, marginal 5 , 7 and 10 , adequate 25,22 and 17 orchards were found in $(0-30,31-60$ and $61-90 \mathrm{~cm})$. The results showed that the soil was low in Fe 3 and $10 \%$ in (31-60 and 61-90 cm), marginal 7,23 and $33 \%$, adequate 83,73 in and $57 \%$ in $(0-30,31-60$ and $61-90 \mathrm{~cm})$. The similar results were found by $[28,29]$. With respect to $\mathrm{B}$ concentration in soils of apple orchards, the results show that none of the orchards were found low in $(0-30 \mathrm{~cm})$ and $(31-60 \mathrm{~cm}), 5$ orchard was found low in $(61-90 \mathrm{~cm})$ depth respectively, marginal 7, 13 and 11, adequate 23,17 and 14 orchards were found in $(0-30,31-60$ and $61-90 \mathrm{~cm})$. The results showed that the B was low $17 \%$ in $(61-90 \mathrm{~cm})$ and marginal 23,43 and $37 \%$, adequate $77,57 \%$ and $47 \%$ in $(0-30,31-60$ and $61-90 \mathrm{~cm})$. These results thus suggested that the soils of apple orchards were low to marginal in $\mathrm{Zn}, \mathrm{Fe}$ and $\mathrm{B}$ to varying levels. The frequency of $\mathrm{Zn}$ deficiency was highest followed by Fe and $\mathrm{B}$ but $\mathrm{Cu}$ and $\mathrm{Mn}$ deficiency in soils were not prevalent. The results were same as [28, 30].

\section{Correlation}

Data presented in (Table 7) shows the relationship of relative concentration of NPK and ABDTPA extractable $\mathrm{Cu}, \mathrm{Fe}$, $\mathrm{Zn}, \mathrm{Mn}$ and Hot water soluble $\mathrm{B}$ with various physical and chemical properties of soil. These were statistically analyzed using simple linear correlation. In addition to these graphs of line of regression were also prepared (Figure 2, 3, $4 \& 5$ ). The ABDTPA extractable $\mathrm{Zn}, \mathrm{Cu}, \mathrm{Fe}, \mathrm{Mn}$ and $\mathrm{B}$ 
had positive non-significant correlation with O.M in the surface and subsurface soil. The micronutrients such as (Fe and $\mathrm{Zn)}$ had negative non-significant correlation with $\mathrm{EC}$ and $\mathrm{pH}$. These results are in conformity with [29]. The ABDTPA extractable $\mathrm{P}$ showed positive non- significant and significant correlation with $\mathrm{OM}$, the results were reported by $[25,29$, 31] .The AB-DTPA extractable $K$ had positive significant correlation with $\mathrm{OM}$ and Lime in the surface and subsurface and negative non-significant correlation with $\mathrm{pH}$. The results were recorded by [32].

Table 4. Number of apple orchards' soil classified as low, marginal or adequate in organic matter, nitrogen, AB- DTPA extractable P and AB- DTPA extractable $K$

\begin{tabular}{|c|c|c|c|c|c|c|c|}
\hline \multirow{2}{*}{ Property } & \multirow{2}{*}{$\begin{array}{l}\text { Soil depth } \\
\quad \text { (cm) }\end{array}$} & \multicolumn{2}{|c|}{ Low } & \multicolumn{2}{|c|}{ Marginal } & \multicolumn{2}{|c|}{ Adequate } \\
\hline & & $\begin{array}{c}\text { No*.of } \\
\text { Orchards }\end{array}$ & $\%$ & $\begin{array}{c}\text { No. of } \\
\text { Orchards }\end{array}$ & $\%$ & $\begin{array}{c}\text { No. of } \\
\text { Orchards }\end{array}$ & $\%$ \\
\hline \multirow{3}{*}{$\begin{array}{c}\text { Organic } \\
\text { mater }\end{array}$} & $0-30$ & 25 & 83.33 & 5 & 16.66 & 0 & 0 \\
\hline & $31-60$ & 26 & 86.66 & 4 & 13.33 & 0 & 0 \\
\hline & $61-90$ & 28 & 93.33 & 2 & 6,66 & 0 & 0 \\
\hline \multirow{3}{*}{ Nitrogen } & $0-30$ & 0 & 0 & 7 & 23.33 & 23 & 76.66 \\
\hline & $31-60$ & 1 & 3.33 & 9 & 30 & 20 & 66.66 \\
\hline & $61-90$ & 4 & 13.33 & 11 & 36.66 & 15 & 50 \\
\hline \multirow{3}{*}{ Phosphorus } & $0-30$ & 0 & 0 & 6 & 20 & 24 & 80 \\
\hline & $31-60$ & 0 & 0 & 11 & 36.66 & 19 & 63.33 \\
\hline & $61-90$ & 0 & 0 & 18 & 60 & 12 & 40 \\
\hline \multirow{3}{*}{ Potassium } & $0-30$ & 1 & 3.33 & 29 & 96.66 & 0 & 0 \\
\hline & $31-60$ & 6 & 20 & 24 & 80 & 0 & 0 \\
\hline & $61-90$ & 18 & 60 & 12 & 40 & 0 & 0 \\
\hline
\end{tabular}

* Out of 30 orchards

Table 5. Ammonium bicarbonate- DTPA extractable $\mathrm{k}$ concentration $\left(\mathrm{mg} \mathrm{kg}^{-1}\right) \&$ Micronutrients concentration in soil $\left(\mathrm{mg} \mathrm{kg}^{-1}\right.$ soil) of apple orchard

\begin{tabular}{|c|c|c|c|c|c|c|}
\hline $\begin{array}{c}\text { K \& } \\
\text { Micronutrient }\end{array}$ & Soil depth (cm) & Mean & SD & Min. & Max. & CV (\%) \\
\hline \multirow{3}{*}{$\mathrm{K}$} & $0-30$ & 70.83 & 6.958 & 60.00 & 85.00 & 9.82 \\
\cline { 2 - 7 } & $31-60$ & 66.83 & 5.645 & 60.00 & 80.00 & 8.44 \\
\cline { 2 - 7 } & $61-90$ & 62.83 & 3.869 & 60.00 & 7.00 & 6.15 \\
\hline \multirow{3}{*}{$\mathrm{Zn}$} & $0-30$ & 2.10 & 0.819 & 0.85 & 3.65 & 39 \\
\cline { 2 - 7 } & $31-60$ & 1.39 & 0.673 & 0.54 & 2.63 & 48 \\
\cline { 2 - 7 } & $61-90$ & 1.00 & 0.535 & 0.32 & 2.44 & 53.5 \\
\cline { 2 - 7 } $\mathrm{Cu}$ & $0-30$ & 4.20 & 1.205 & 2.01 & 6.16 & 28.69 \\
\cline { 2 - 7 } & $31-60$ & 3.84 & 1.314 & 1.91 & 6.10 & 34.21 \\
\hline \multirow{3}{*}{$\mathrm{Fe}$} & $61-90$ & 3.55 & 1.383 & 1.11 & 5.91 & 38.95 \\
\cline { 2 - 7 } & $0-30$ & 6.95 & 1.917 & 3.05 & 9.66 & 27.58 \\
\cline { 2 - 7 } & $31-60$ & 6.40 & 1.858 & 2.34 & 8.89 & 29.03 \\
\hline \multirow{3}{*}{$\mathrm{Mn}$} & $61-90$ & 5.53 & 1.967 & 1.90 & 8.78 & 35.56 \\
\cline { 2 - 6 } & $0-30$ & 5.47 & 1.574 & 2.90 & 7.72 & 28.77 \\
\cline { 2 - 6 } & $31-60$ & 4.76 & 1.475 & 2.56 & 7.01 & 30.98 \\
\hline \multirow{3}{*}{$\mathrm{B}$} & $61-90$ & 4.23 & 1.459 & 2.01 & 7.01 & 34.49 \\
\cline { 2 - 6 } & $0-30$ & 1.68 & 0.706 & 0.72 & 3.16 & 42.02 \\
\cline { 2 - 6 } & $31-60$ & 1.44 & 0.756 & 0.55 & 3.05 & 52.5 \\
\hline
\end{tabular}


Table 6. Number of apple orchards classified as low, marginal or adequate in micronutrients based on soil concentration

\begin{tabular}{|c|c|c|c|c|c|c|c|}
\hline \multirow{2}{*}{ Micronutrient } & \multirow{2}{*}{$\begin{array}{c}\text { Soil } \\
\text { depth } \\
\text { (cm) }\end{array}$} & \multicolumn{2}{|c|}{ Low } & \multicolumn{2}{|c|}{ Marginal } & \multicolumn{2}{|c|}{ Adequate } \\
\hline & & $\begin{array}{c}\mathrm{No}^{*} \text {.of } \\
\text { Orchards }\end{array}$ & $\%$ & $\begin{array}{c}\text { No. of } \\
\text { Orchards }\end{array}$ & $\%$ & $\begin{array}{c}\text { No. of } \\
\text { Orchards }\end{array}$ & $\%$ \\
\hline \multirow{3}{*}{$\mathrm{Zn}$} & $0-30$ & 2 & 6.66 & 7 & 23.33 & 21 & 70 \\
\hline & $31-60$ & 7 & 23.33 & 11 & 36.66 & 12 & 40 \\
\hline & $61-90$ & 14 & 46.66 & 12 & 40 & 4 & 13.33 \\
\hline \multirow{3}{*}{$\mathrm{Cu}$} & $0-30$ & 0 & 0 & 0 & 0 & 30 & 100 \\
\hline & $31-60$ & 0 & 0 & 0 & 0 & 30 & 100 \\
\hline & $61-90$ & 0 & 0 & 0 & 0 & 30 & 100 \\
\hline \multirow{3}{*}{$\mathrm{Fe}$} & $0-30$ & 0 & 0 & 5 & 6.66 & 25 & 83.33 \\
\hline & $31-60$ & 1 & 3.33 & 7 & 23.33 & 22 & 73.33 \\
\hline & $61-90$ & 3 & 10 & 10 & 33.33 & 17 & 56.66 \\
\hline \multirow{3}{*}{$\mathrm{Mn}$} & $0-30$ & 0 & 0 & 0 & 0 & 30 & 100 \\
\hline & $31-60$ & 0 & 0 & 0 & 0 & 30 & 100 \\
\hline & $61-90$ & 0 & 0 & 0 & 0 & 30 & 100 \\
\hline \multirow{3}{*}{ B } & $0-30$ & 0 & 0 & 7 & 23.33 & 23 & 76.66 \\
\hline & $31-60$ & 0 & 0 & 13 & 43.33 & 17 & 56.66 \\
\hline & $61-90$ & 5 & 16.66 & 11 & 36.66 & 14 & 46.66 \\
\hline
\end{tabular}

*Out of 30 orchards

Table 7. Correlation of soil nutrients with soil properties

\begin{tabular}{|c|c|c|c|c|c|}
\hline \multirow{2}{*}{ Soil nutrients } & \multirow{2}{*}{$\begin{array}{c}\text { Depths } \\
(\mathbf{c m})\end{array}$} & \multicolumn{4}{|c|}{ Soil properties } \\
\hline & & $\mathbf{O M}$ & Lime & pH & ECs \\
\hline \multirow{3}{*}{$\mathbf{N}$} & $0-30$ & 0.312 & 0.358 & 0.114 & -0.227 \\
\hline & $31-60$ & 0.312 & 0.163 & 0.137 & -0.282 \\
\hline & $61-90$ & 0.306 & 0.234 & 0.179 & -0.429 \\
\hline \multirow{3}{*}{$\mathbf{P}$} & $0-30$ & 0.257 & 0.182 & -0.054 & 0.083 \\
\hline & $31-60$ & 0.369 & 0.043 & 0.010 & 0.091 \\
\hline & $61-90$ & 0.355 & -0.125 & 0.029 & -0.152 \\
\hline \multirow{3}{*}{$\mathbf{K}$} & $0-30$ & $0.413^{*}$ & 0.309 & -0.024 & 0.069 \\
\hline & $31-60$ & $0.434^{*}$ & 0.001 & -0.037 & 0.063 \\
\hline & $61-90$ & $0.409^{*}$ & 0.068 & -0.075 & -0.081 \\
\hline \multirow{3}{*}{ Zn } & $0-30$ & 0.239 & -0.116 & -0.003 & -0.026 \\
\hline & $31-60$ & 0.106 & 0.172 & -0.085 & 0.304 \\
\hline & $61-90$ & 0.119 & 0.059 & -0.190 & 0.147 \\
\hline \multirow{3}{*}{$\mathbf{C u}$} & $0-30$ & 0.131 & -0.274 & -0.191 & 0.182 \\
\hline & $31-60$ & 0.170 & -0.217 & 0.166 & 0.090 \\
\hline & $61-90$ & 0.219 & -0.089 & 0.266 & 0.072 \\
\hline \multirow{3}{*}{$\mathbf{F e}$} & $0-30$ & 0.092 & 0.107 & -0.180 & 0.117 \\
\hline & $31-60$ & 0.121 & -0.065 & 0.264 & -0.037 \\
\hline & $61-90$ & 0.069 & 0.053 & 0.292 & -0.066 \\
\hline \multirow{3}{*}{ Mn } & $0-30$ & 0.043 & 0.134 & 0.112 & 0.014 \\
\hline & $31-60$ & 0.026 & 0.064 & 0.021 & 0.109 \\
\hline & $61-90$ & 0.243 & -0.287 & 0.179 & 0.212 \\
\hline \multirow{3}{*}{ B } & $0-30$ & 0.031 & 0.033 & 0.141 & -0.053 \\
\hline & $31-60$ & 0.036 & 0.118 & 0.254 & 0.189 \\
\hline & $61-90$ & 0.225 & 0.036 & 0.240 & $0.364^{*}$ \\
\hline
\end{tabular}

\footnotetext{
* $\mathrm{r}_{0.05}$
}

$* * \mathrm{r}_{0.01}$ 


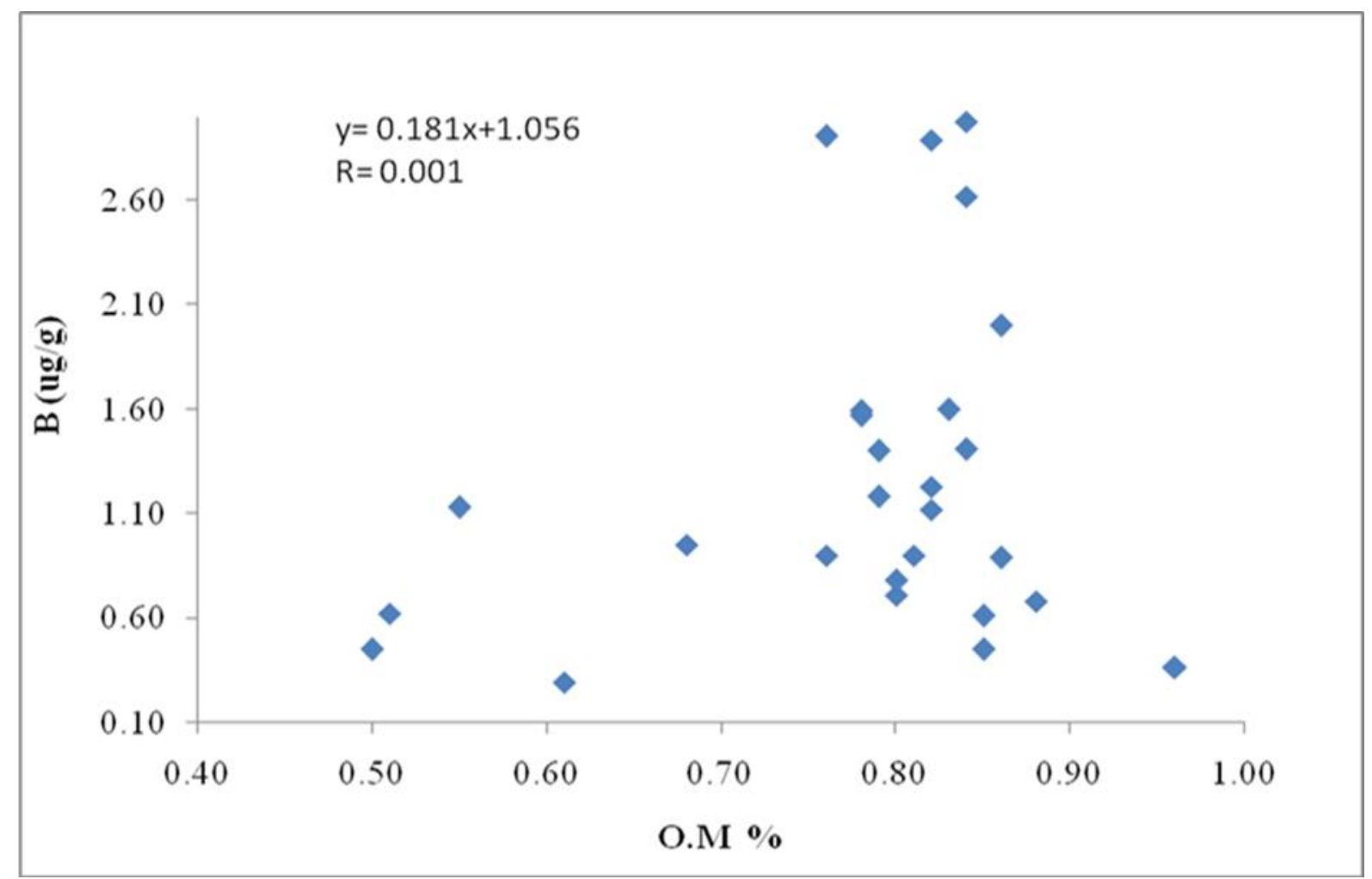

Figure 2. Relationship between B with O.M at surface

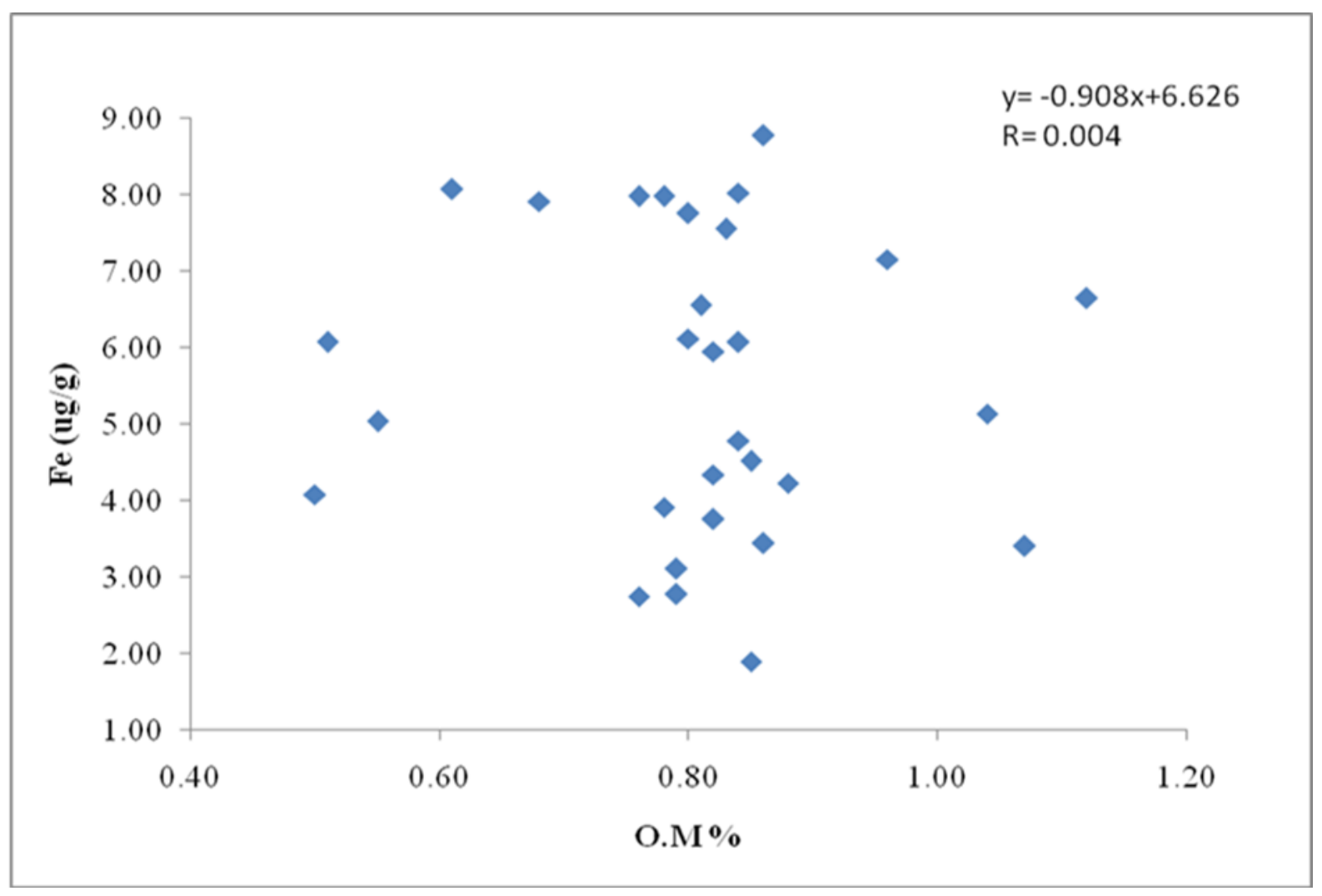

Figure 3. Relationship between AB-DTPA extractable Fe with O.M at surface 


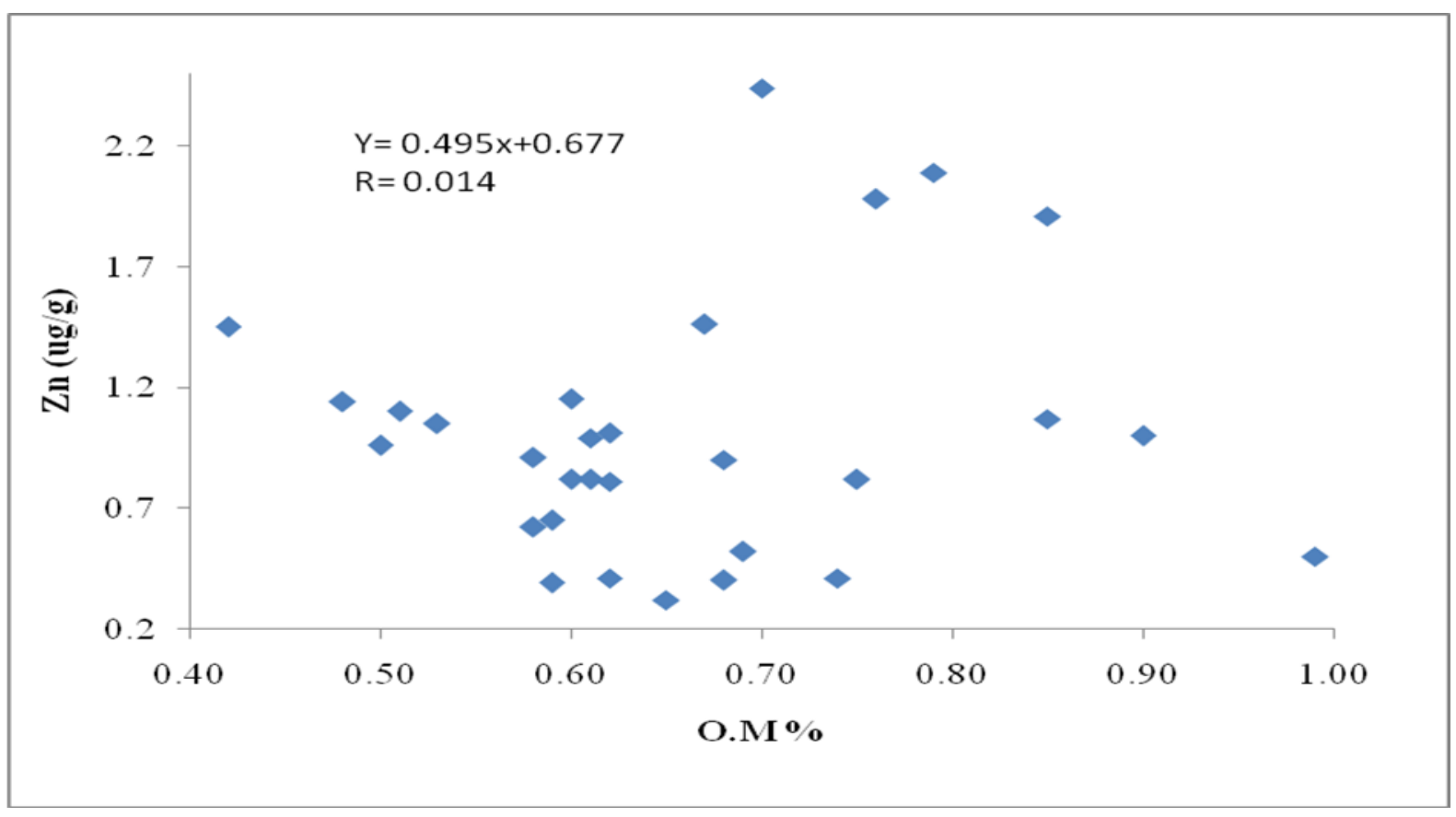

Figure 4. Relationship between AB-DTPA extractable $\mathrm{Zn}$ with O.M at surface

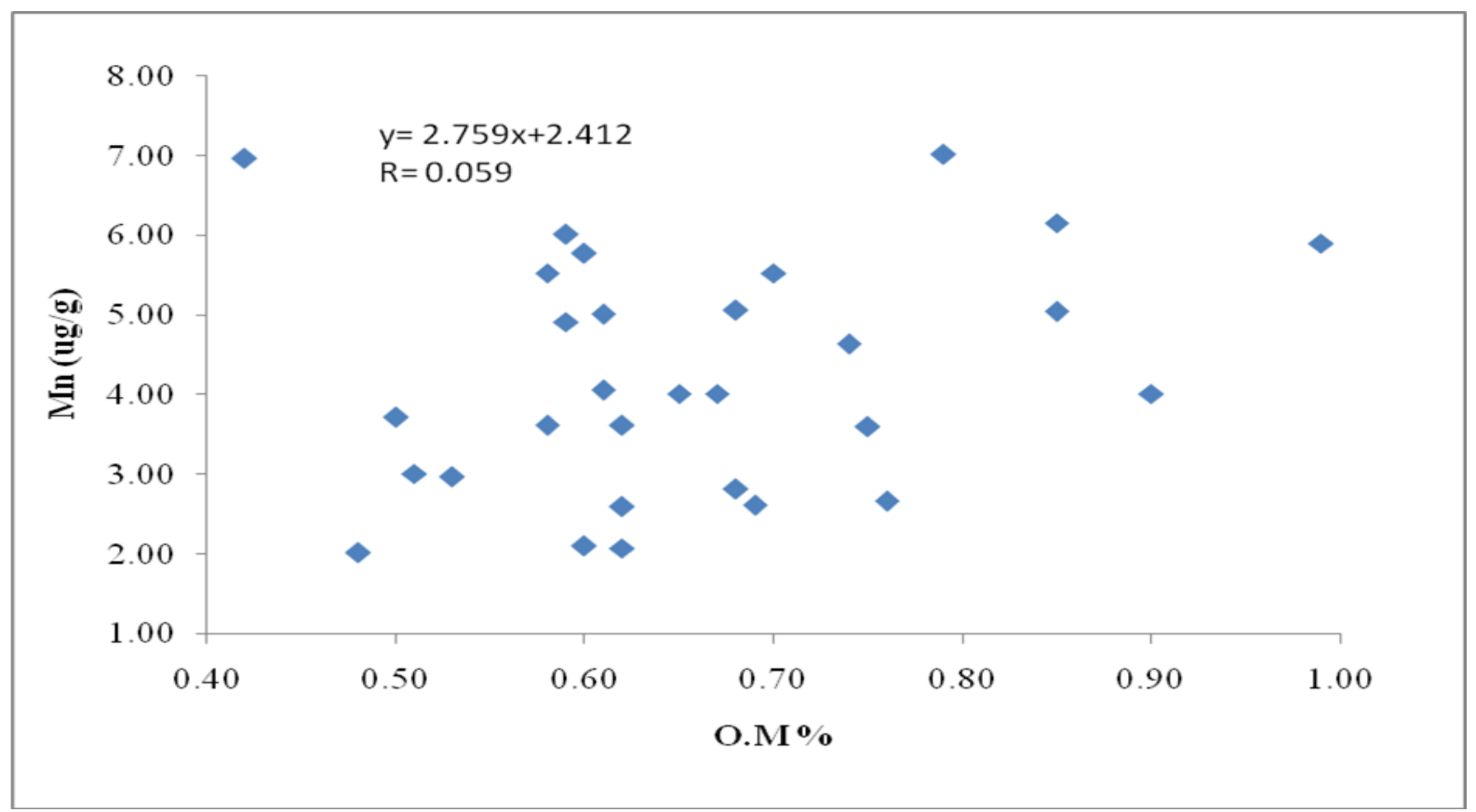

Figure 5. Relationship between AB-DTPA extractable Mn with O.M at surface

\section{Conclusion and recommendations}

Apple orchards soils in Qilla Saifullah were found deficient in $\mathrm{Zn}, \mathrm{Fe}$ and $\mathrm{B}$ and their concentration decreased with increasing soil depth; The surface soils generally contained more mineral nitrogen than subsurface soils the results showed that the orchard were found low 3 and $13 \%$ in (31-60 and 61-90 cm), marginal 23, 30 and $37 \%$, adequate 77,67 and $50 \%$ orchards were found in (0-30, 31-60 and $61-90 \mathrm{~cm})$; Phosphorus and potassium were deficient in most of orchards in subsurface and further decreased to soil 
depth; organic matter was also deficient in subsurface. It ranged $83 \%$ to $93 \%$ in (0-30 and $61-90 \mathrm{~cm})$, marginal from $17 \%$ in $(0-$ $30 \mathrm{~cm})$ to $7 \%$ in $(61-90 \mathrm{~cm})$ and orchards were inadequate at all depths; $\mathrm{pH}$ reflected alkaline soils; EC of all soil were below 4.0 $\mathrm{mScm}^{-1}$ that showed non-saline soils and soil was light in texture. Experiments should be conducted for the nutrients in low and marginal orchards to find out the optimum dose of these nutrients, and orchards classified as low and marginal should be fertilized with macro and micronutrients fertilizer to maintain soil fertility.

\section{Authors' contributions}

Conceived and designed the experiments: $\mathrm{Z}$ Ullah \& ZU Haq, Performed the experiments: Z Ullah \& ZU Haq, Analyzed the data: Z Ullah \& MR Siddiqui, Contributed materials/ analysis/ tools: Saduddin, Wrote the paper: Z Ullah

\section{References}

1. Khair SM, Shah NA, Khan S, Kasi MA, Sattar SA \& Razzaq A (2002). Comparative marketing margins for Kaja (Red Delicious and Shin Kulu Golden Delicious) apple in Pishin. Asian J Plant Sci 1(2): 190-192.

2. Agriculture Statistics of Pakistan (2011). pp 92-93

3. Zydlik Z \& Pachilak E (2001). Fertigation effects on the concentration of mineral component in the soil, leaves, yield and the quality of fruits in two apple-tree cultivars. Acta Hort pp 564-567.

4. Nachtigall GR \& Dechen AR (2006). Seasonality of nutrients in leaves and fruits of apple trees. Sci Agri 63(5): 493-501.

5. Woodbridge CG (1954). Zn deficiency in fruit tree in the Okanagan in british Columbia. Can J Agri Sci 34: 545551.

6. Papadakisa I, Theriosa N \& Tsirakogloua V (2005). Foliar treatment of $\mathrm{Mn}$ deficient 'Washington navel' orange trees with two Mn sources. Sci Hort 106(1): 7075.
7. Woodbridge CG (1955). The B requirement of stone fruit trees. Can $\mathrm{J}$ Agri Sci 35: 282-286.

8. Soltanpour PN (1985). Use of ammonium bicarbonate-DTPA soil test to calculate elemental availability and toxicity. Communi Soil Sci Plant Anal 16: 322-38.

9. Bremner JM \& Mulvanay CS (1982). Kjedhal Method. In the method of soil analysis part-2: Chemical and microbiological properties. Amer Soc Agron Madison WI pp 903-948.

10. Berger KC \& Truog E (1939). Boron Determination in Soils and Plants. Anal Chemistry 11 (10): 540-545.

11. Jackson ML (1998). Soil chemical analysis. Prentice Hall. Inc. Englewood, Cliffs. pp 197-200.

12. Nelson DW \& Sommers LE (1996). Total carbon, organic carbon and organic matter. In: Methods of soil analysi part 3. Inc: Madison, Wasconsin, U. S. A. pp 961-1010.

13. McLean EO (1976). Chemistry of soil aluminium. Communications Soil Sci Plant Annuals pp 7: 619-636.

14. Bhatti AU (2006). Statistical procedures for examination of agriculture research experiments. I $^{\text {st }}$ ed. Deptt. Soil \& Environ Sci NWFP Agri Univ Peshawar. pp 45-63.

15. Rogers WS (1940). Root Studies VIII. Apple root growth in relation to rootstock, soil, seasonal and climatic factors. 17(2): 99-130.

16. Nofal OA \& Khalifa RKM (2002). Nutritional diagnosis of Anna apple trees in some Egyptian soils . Pak J Biological Sci 5(4): 398-400.

17. Umalia PB, Oliver DP, Forrester S, Chittleborough DJ, Hutson JL, Kookana RS \& Ostendorf B (2012). The effect of terrain and management on the spatial variability of soil properties in an apple orchard. CATENA 93: 38-48.

18. Chang SC \& Jackson ML (1958). Soil phosphorus fractions in some representative soils. J Soil Sci 9(1): 
109-119.

19. Glover JD, Reganold JP \& Andrews PK (2000). Systematic method for rating soil quality of conventional, organic, and integrated apple orchards in Washington State Author links open overlay panel. Agriculture, Ecosystems \& Environment 80(1-2): 29-45.

20. Haynes RJ \& Goh KM (1980). Distribution and budget of nutrients in a commercial apple orchard. Plant Soil 56: 445-457.

21. Asfar (1993). Fertility soil of lalazar in kaghan valley. M.Sc (Hons), thesis Agriculture University Peshawar. pp 19-23.

22. Neilsen D \& Neilsen GH (2002). Efficient use of nitrogen and water in high-density apple orchards. Hort Tech 12(1): 119-125.

23. Goh KM \& Malakouti MJ (2008). Preliminary nitrogen, phosphorus, potassium, calcium and magnesium DRIS norms and indices for apple orchards in Canterbury, New Zealand. Communications Soil Sci Plant Analysis 23: 1371-1385.

24. Raza K \& Sarir MS (2007). Fertility evaluation of organic soil of northern area. MSc (Hons), thesis of University of Agriculture, Peshawar. pp 21-24.

25. Khatak RA \& Hussain Z (2007). Evaluation of soil fertility grade and nutrition of orchards. Soil Environ 26(1): 22-32.

26. Chaudhry AR, Husan G \& Mala DM (1992). Crop response to potash application report in Panjab. Annual Repot 1991-1992. Soil fertility survey. Institute Lahore. pp 35-41.

27. Parveen S, Nazif $W$, Khatak IA, Ahmad MF \& Khan A (2006). Nutritional condition of dissimilar orchards which is irrigated waste water in District Peshawar. J Agri Bio Sci 1(1): 42-50.

28. Goswami D \& Kumar RA (2002). Fertility status of soil Citrus Research Station Tunsakia AAU, Assam. Annual-of-Agri-bio-research. $\quad 7(2)$ : 39-142.

29. Rajakumar GK, Patail CV, Prakash SS \& Math KK (1996). Micronutrients distribution in paddy soils in relation to parent material and soil properties. J Agric Sci 9(2): 231-235.

30. Shah Z \& Shahzad K (2008). Micronutrients status of apple orchards in swat valley of North West Frontier province of Pakistan. $J$ Soil Environ 27(1): 123-130.

31. Khalifa EM, El-doskey MA, Gameh MA \& Faragallah ME (1996). Status of some micronutrients and there relation to mineral composition of the Nile valley desert interence zone soil, East of Assiut city. J Agri Sci 27(3): 107-127.

32. Nazir A, Abid M, Hussain K, Akram M \& Yousaf (2003). Evaloation of nutrients status in rice growing area of Panjab. Soil and Water testing laboratory Multan. Asian J Plant Sci 2(5): 449-453. 